Full Length Article

\title{
Isolation of a Thermostable Alkaline Cellulase-producing Bacterium Strain from a Garbage Dump
}

\author{
Zhengang Ma ${ }^{1,2 \dagger}$, Jing Tang ${ }^{3 \dagger}$, Xiqian Lan ${ }^{1,4}$, Hongxiu Wen ${ }^{1,4}$, Quanmei Chen ${ }^{1}$, Tian $\mathrm{Li}^{1}$, Jinshan $\mathrm{Xu}^{2}$, Chunfeng $\mathrm{Li}^{1 *}$ \\ and Zeyang Zhou ${ }^{1,2}$ \\ ${ }^{1}$ The State Key Laboratory of Silkworm Genome Biology, Southwest University, Chongqing, China \\ ${ }^{2}$ College of Life Sciences, Chongqing Normal University, Chongqing, China \\ ${ }^{3}$ College of Life Sciences, Guizhou Normal University, Guiyang, China \\ ${ }^{4}$ Renal Molecular Research Laboratory, Feinstein Institute for Medical Research, Hofstra North Shore LIJ Medical School, \\ New York, USA \\ *For correspondence: licf@swu.edu.cn \\ ${ }^{\dagger}$ Equal contributor
}

\begin{abstract}
Thermostable alkaline cellulases can resist high temperature and high $\mathrm{pH}$, which make them widely applicable in the industries of food, detergent, paper making, and biomass utilization. To obtain favorite thermostable alkaline cellulaseproducing bacterial strains, these bacteria were isolated from collected soil and plant putrefaction samples in long-term garbage dumps. One bacterium strain from lime-applied garbage dumps, named as SWU-27, was picked up since its crude enzyme showed stronger activities of cellubiohydrolase, endoglucanase, and $\beta$-glucosidase. All these activities could tolerate the treatment of high temperature (up to $80^{\circ} \mathrm{C}$ ) and endoglucanase and $\beta$-glucosidase activities could even tolerate high $\mathrm{pH}$ (over 10). Taxonomic study showed that strain SWU-27 is another geographic strain of Gram-negative Klebsiella pneumoniae. In conclusion it is suggested that lime-applied dumps are preferable places to isolate novel thermostable alkaline cellulaseproducing bacterial strains. (C) 2015 Friends Science Publishers
\end{abstract}

Keywords: Bacteria; Garbage dump; Klebsiella pneumonia; Lime; Thermostable alkaline cellulase

\section{Introduction}

Cellulose is the most abundant biomass on the earth for its annual output as high as $10^{11}$ tons that is produced by the plants' photosynthesis (Shuler, 1980). The biological degradation and conservation of cellulose constitute a significant component of the natural carbon cycle (Sleat et al., 1984). Cellulose is known as an important reproducible resource for its vast existence and potential applications. However, due to their complicated and insoluble structures, most of them cannot be directly used and are usually discarded, resulting in a serious environmental pollution.

More and more biotechnologist are focusing on the processes for the conversion of renewable lignocellulosic substrates to fermentable sugars that can be used for the production of ethanol, which happens to be one of the most important biofuel (Singh et al., 2008). The effective conversion can help to mitigate energy and food crisis (Lutzen et al., 1983). At present, cellulose microbial fermentation takes cellulose as a major source for industrial fuels and chemicals, which in turn reduces the accumulation of cellulosic wastes (Sleat et al., 1984). Cellulases produced by microorganisms play an important role in the biodegradation of cellulose. Even though the Trichoderma cellulolytic enzyme systems have been employed during most of the enzymatic conversion of cellulose to fermentable sugars, more effective enzyme complex can be produced from other microorganisms (Lutzen et al., 1983). Therefore, challenging as it is, seeking an available cellulose-decomposing organism bears significant meanings. Cellulase is a complex enzyme system consisted of endoglucanase, cellubiohydrolase, and $\beta$-glucosidase. Because of their characteristics in tolerance of high temperature and high $\mathrm{pH}$, thermostable alkaline cellulases can be widely used in various industries including food, detergent, paper making, and biomass utilization. Many microorganisms, such as Trichoderma, Aspergillus and Clostridium have been reported as the cellulase producing strains for their thermophilic degradation of cellulose (Gritzali and Brown, 1979; Sissons et al., 1987; Zhou et al., 2008). However, large-scale cultivation of fungi and actinomycetes are usually costly since they grow slow and coproduce high viscous polymers. Comparatively, bacteria 
are more suitable for large scale production of cellulases.

Thermostable alkaline cellulolytic enzyme-producing bacteria have been isolated from soil (Hakamada et al., 1997), and marine sediments (Annamalai et al., 2012). However, all these environments are not extremely hot or alkaline, so the chance to find a favorite strain is relatively low. In some places of China, people spray lime to the dump for sterilization, which makes the dump and the soil there very hot and alkaline. The sites of long-term stacking for discarded plants have a lot of putrefaction containing abundant cellulose for the growth of cellulose-utilizing strains. To speculate that some bacteria in these environments can produce thermostable alkaline cellulolytic enzymes, one primary objective these investigations was to explore and identify the strain of bacterium, which produces several kinds of thermostable alkaline cellulolytic enzymes.

\section{Materials and Methods}

\section{Isolation of Bacterial Strains}

Putrefying soil samples were collected from long-term stacking dumps around Southwest University, China. All these dumps had been applied with lime for sterilization purpose. Cellulose-producing bacterial strains were isolated from these samples following classical method. Briefly, $1 \mathrm{~g}$ of the sample was resuspended before settled in $100 \mathrm{~mL}$ deionized water, and the upper suspension fluid was serially diluted, $100 \mu \mathrm{L}$ of each dilution were subcultured on a modified sodium carboxymethycellulose (CMCNa) screening medium consisting of $10 \mathrm{~g} \mathrm{CMCNa}, 1 \mathrm{~g}$ tryptone, $4 \mathrm{~g}\left(\mathrm{NH}_{4}\right)_{2} \mathrm{SO}_{4}, 2 \mathrm{~g} \mathrm{KH}_{2} \mathrm{PO}_{4}, 0.5 \mathrm{~g} \mathrm{MgSO}_{4} \cdot 7 \mathrm{H}_{2} \mathrm{O}$ in 1000 $\mathrm{mL}$ ultrapure water ( $\mathrm{pH}$ 7.0) (Mandels and Reese, 1957). Cultures were incubated at $37^{\circ} \mathrm{C}$ under aerobic conditions until clear colonies appeared on the plate. Then Congo red solution $(1 \mathrm{mg} / \mathrm{mL})$ was added to the plate, and the colonies surrounded by transparent zone were regarded as cellulaseproducing bacteria and were subsequently purified by repeated streaking onto $\mathrm{CMCNa}$ medium for three times. The ability of these colonies to produce $\beta$-glucosidase was further examined on a plate based on the esculin screening medium containing $1 \mathrm{~g}$ tryptone, $0.5 \mathrm{~g}$ yeast extraction, $1 \mathrm{~g}$ $\mathrm{NaCl}, 0.25 \mathrm{~g}$ Ammonium iron (III) critrate together with 0.1 g esculin in $100 \mathrm{~mL}$ distilled water (Kwon et al., 1994), and the activity was showed by a black circle surrounding the colonies.

\section{Cellulolytic Enzyme Assay}

CMCNa, Whatman No. 1 filter paper and Esculin, were applied to measure the activities of endoglucanase, exoglucanase, and $\beta$-glucosidase, respectively. The organism was incubated $(1 \% \mathrm{v} / \mathrm{v})$ aerobically in $500 \mathrm{~mL}$ conical flask containing $\mathrm{CMCNa}$ liquid medium with additional $1.5 \%(\mathrm{~g} / \mathrm{v})$ bran at $37^{\circ} \mathrm{C}$ on a reciprocal shaker. After 4 days of cultivation, cell-free supernatant was collected by centrifugation and was used for the enzyme assay. 3, 5-dinitrosalicylic acid (DNS) method (Miller, 1959) quantified by spectrometric determination of reducing sugars was used to measure the crude cellulase activity following a modified procedure (Trivedi et al., 2011). Briefly, after incubation at $35^{\circ} \mathrm{C}$ for $30 \mathrm{~min}$, the reaction mixture that contained supernatants $(1 \mathrm{~mL})$, substrate solution $(2 \mathrm{~mL})$ in $2 \mathrm{~mL} 20 \mathrm{mM}$ Citric acid sodium buffer ( $\mathrm{pH} 7.0$ ), was replenished of $2 \mathrm{~mL}$ DNS reagent and heated to $99^{\circ} \mathrm{C}$ for $10 \mathrm{~min}$ in a water bath system. An absorbance at $546 \mathrm{~nm}$ exhibited the amount of released reducing sugar in the reaction mixture. One unit of enzyme activity was defined as the amount of enzyme liberated $1 \mu \mathrm{mol}$ reducing sugar. The substrate solutions used were $1 \%(\mathrm{w} / \mathrm{v}) \mathrm{CMCNa}$, $4.0 \mathrm{mg} / \mathrm{mL}$ Esculin and 1\% (w/v) Whatman No. 1 filter paper.

\section{Taxonomic Study}

Biochemical and morphological analysis of the strain were performed following Bergey's Manual (Garrity et al., 2005). Total genomic DNA was extracted according to the methods by Huber et al. (Huber et al., 2002). Universal primers $8 \mathrm{~F}$ (5'-AGAGTTTGATCCTGGCTCAG-3') and 1512R (5'ACGGCTACCTTGTTACGACTT-3') were employed to amplify the $16 \mathrm{~S}$ rDNA by polymerase chain reaction. The PCR mixture was composed of $2.0 \mu \mathrm{L}$ of $2.5 \mathrm{mM}$ dNTPs, $2.0 \mu \mathrm{L}$ of $2.5 \mathrm{mM} \mathrm{MgCl} 2,2.5 \mu \mathrm{L}$ of $10 \times \mathrm{PCR}$ buffer $\left(\mathrm{Mg}^{2+}\right.$ free), $1.0 \mu \mathrm{L}$ of each primer ( $10 \mathrm{mM}), 0.25 \mu \mathrm{L}$ of rTaq DNA polymerase $(2.5 \mathrm{U} / \mu \mathrm{L})$ (TaKaRa, Dalian), $1.0 \mu \mathrm{L}$ of template DNA, in a final volume of $25 \mu \mathrm{L}$. PCR amplification was carried out as follows: $94^{\circ} \mathrm{C}$ for $4 \mathrm{~min} ; 35$ cycles at $94^{\circ} \mathrm{C}$ for $20 \mathrm{~s}, 55^{\circ} \mathrm{C}$ for $30 \mathrm{~s}$, and $72^{\circ} \mathrm{C}$ for $80 \mathrm{~s}$; $72^{\circ} \mathrm{C}$ for $10 \mathrm{~min}$. The $16 \mathrm{~S}$ rDNA gene was cloned into pMD19-T vector. Nucleotide sequence of $16 \mathrm{~S}$ rDNA was sequenced and identified through the online BLAST program. Multiple alignment was carried out with the CLUSTALX and a neighbor-joining phylogenetic tree was reconstructed using the MEGA program version 4.0 (Rastogi et al., 2009).

\section{Results}

\section{Microorganism and Cellulolytic Activity}

From the collected samples, more than 100 strains of cellulase-producing bacteria were isolated. One stain, designated as SWU-27, was selected for further study because it exhibited stronger cellulase activity. This strain showed a transparent zone on CMCNa agar plate (diameter of clearance zone: colony/3.78:1) and black hydrolysis circle on Esculin plate (diameter of black hydrolysis circle: colony/2.87:1), indicating its potential activities of CM Case and $\beta$-glucosidase (Fig. 1).

To test the cellulolytic activity, SWU-27 strain was cultured in $\mathrm{CMCNa}$ medium and the cell-free supernatant 
Table 1: Biochemical and physiological tests of strain SWU-27

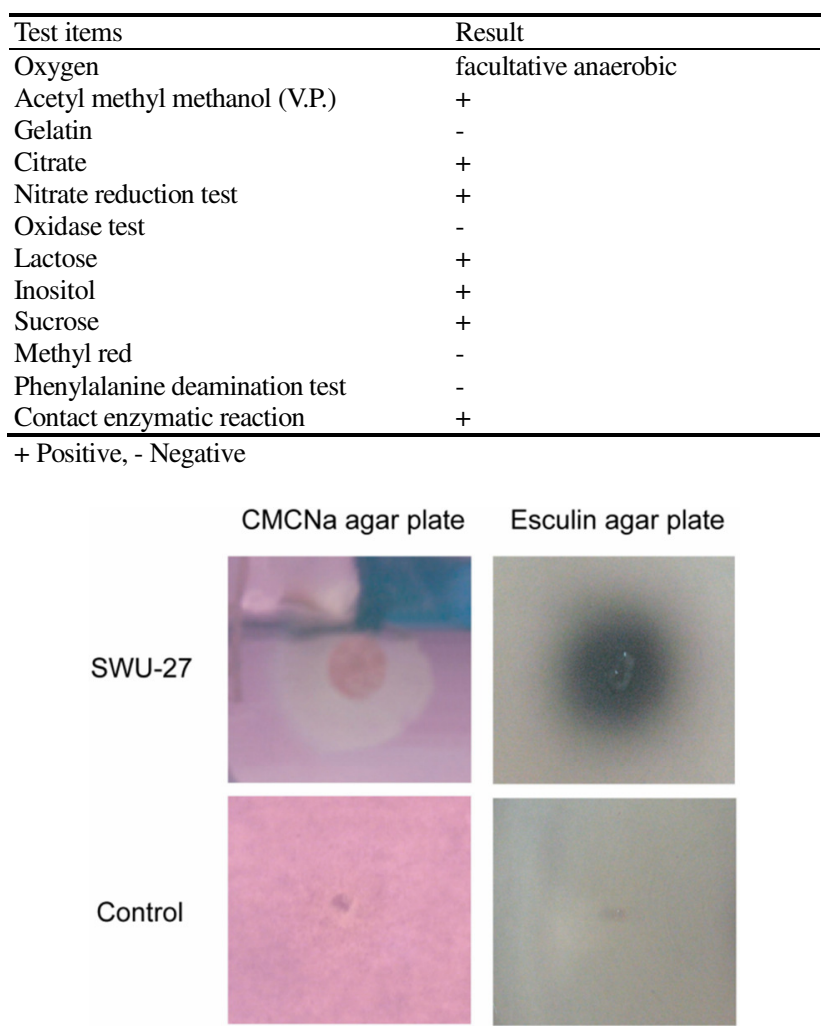

Fig. 1: The screening plate for cellulase-producing strain SWU-27. Strain SWU-27 was inoculated onto CMCNa plate, and was cultured at $37^{\circ} \mathrm{C}$ for about $24 \mathrm{~h}$. Congo red was then added to show cellulase activity. A clearance zone after Congo red stain on CMCNa plate indicated a CMCase activity and a black hydrolysis circle around the strain on Esculin plate showed the capacity of hydrolyzing oligosaccharide. E. coli strain DH5a was used as a negative control

was collected as crude enzyme for the activity assay. Results showed the activity of endoglucanase, cellubiohydrolase and $\beta$-glucosidase were $10.7 \mathrm{U} / \mathrm{mL}, 15.91$ $\mathrm{U} / \mathrm{mL}$ and $20.1 \mathrm{U} / \mathrm{mL}$, respectively. These activities were stronger than those of Clostridium and Bacillus flexus (Benoit et al., 1992; Trivedi et al., 2011). Strain SWU-27 was stored at the State Key Laboratory of Silkworm Genome Biology, Southwest University, Chongqing, China.

\section{Effects of $\mathrm{pH}$ and Temperature on the Cellulase Activities of Strain SWU-27}

Usually, enzymatic activities are sensitive to $\mathrm{pH}$ and temperature changes. To characterize the cellulolytic enzymes of strain SWU-27, the activity profile of the crude enzyme was analyzed. The optimum activities of all the cellulases were around $\mathrm{pH}$ 6.0-7.0 (Fig. 2a). Interestingly, the activities of all these three cellulase components were extremely active in the $\mathrm{pH}$ range from 5.0 to 10.0. As shown in Fig. 2b, their optimum temperatures were about $40-50^{\circ} \mathrm{C}$. Notably, both the endoglucanase and cellubiohydrolase could effectively hydrolyze their substrates in the temperature range from 20 to $90^{\circ} \mathrm{C}$. In contrast, most previously reported bacteria did not functionally work under the wide range of temperature and $\mathrm{pH}$ (Sleat et al., 1984; Tai et al., 2004; Taya et al., 1988; Trivedi et al., 2011).

\section{Stability Analysis of the Cellulolytic Enzyme Activity}

Many enzymes are very sensitive to high temperature and high $\mathrm{pH}$. However, for the application in industry, cellulases are usually required to endure high temperature and high $\mathrm{pH}$. To detect the stability of the crude enzyme of strain SWU27 , firstly the crude enzyme was pre-treated under different temperatures or $\mathrm{pH}$ conditions for $30 \mathrm{~min}$, and then the residual enzyme activities were determined. Results showed that the endoglucanase and $\beta$-glucosidase were very stable under a wide range of $\mathrm{pH}$, and more than $60 \%$ activities remained after the treatment under $\mathrm{pH} 5-12$. While the cellubiohydrolase was more sensitive to $\mathrm{pH}$ variation, and only $20 \%$ activity remained after the treatment under $\mathrm{pH}$ value below 5 or over 9 (Fig. 2c). Interestingly, all these enzyme activities showed resistance against high temperature. After the treatment for $30 \mathrm{~min}$, more than $90 \%$, $70 \%$, and $60 \%$ activities remained in the $\beta$-glucosidase, cellubiohydrolase, and endoglucanase, respectively (Fig. 2d). Compared with those from Bacillus, Geobacillus, and Trichoderma (Annamalai et al., 2012; Bhikhabhai et al., 1984; Hakamada et al., 1997; Tai et al., 2004), the cellulolytic enzymes are more stable against high temperature.

\section{Taxonomic Classification of Strain SWU-27}

Strain SWU-27 was Gram-negative, motile, and rod-shaped (0.6-0.9 by 1.2-2.1 $\mu \mathrm{m}$ ) without spore or flagellum (Fig. 3). It could utilize lactose, inositol and sucrose as the carbon source. The contact enzymatic reaction exhibited a positive result. Other biochemical properties were listed in Table 1. All the properties were in accordance with the standard identification of Klebsiella (Garrity et al., 2005).

Partial 16S rDNA sequence of strain SWU-27 was determined and the BLAST results showed that its share of more than $99 \%$ identifies it with those of Klebsiella at nucleic acid level. Based on multiple alignments of all related 16S rDNA sequences comprised of ten sequences derived from seven Klebsiella and four elements from other species, the NJ phylogenetic tree was constructed for further identification. Strain SWU-27 is the member of clade comprised of various Klebsiella pneumoniae strains (Fig. 4). All these results demonstrate that SWU-27 belongs to Klebsiella, termed as K. pneumoniae strain SWU-27. The 
(a)

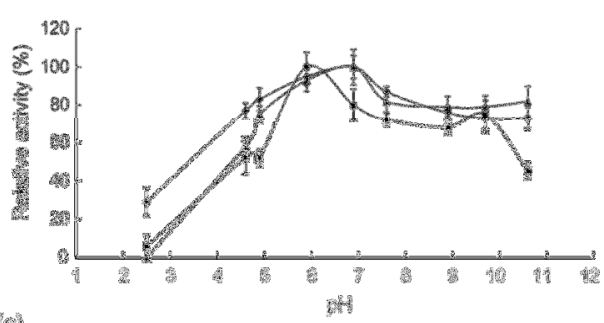

16

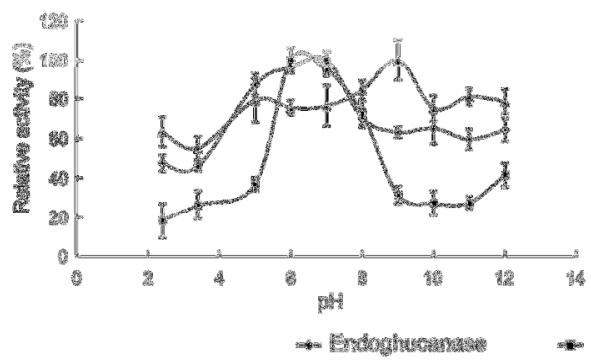

(b)

(19)
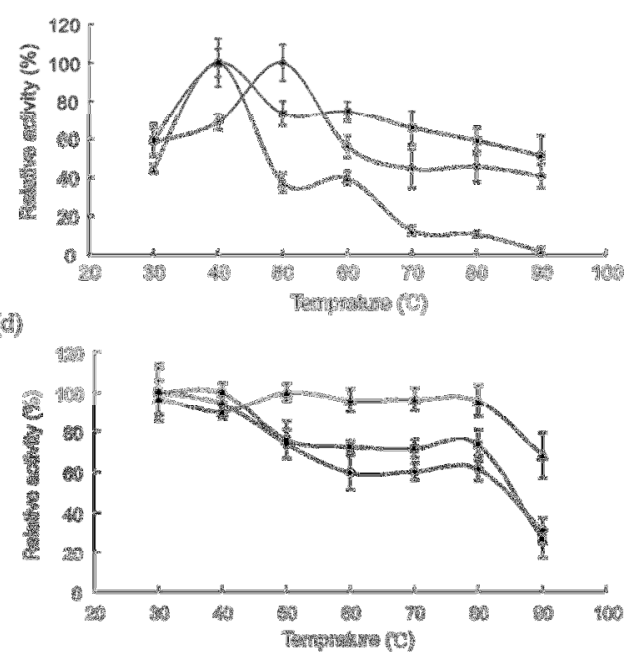

Fig. 2: Analysis of the cellulase activities of strain SWU-27. After 4 days of cultivation, cell-free supernatant of strain SWU-27 was collected for the enzyme assay. The DNS method was used to measure the crude cellulase activity. The optimum $\mathrm{pH}$ (a) and temperature (b) were determined by measuring the enzyme activity under different $\mathrm{pH}$ at $40^{\circ} \mathrm{C}$ or various temperatures under $\mathrm{pH}$ 7.0. The stability of the celluloytic enzyme under different $\mathrm{pH}$ (c) was determined by incubating the enzyme in different buffers $(20 \mathrm{mM}$ sodium phosphate, $\mathrm{pH} 5-7 ; 20 \mathrm{mM}$ Tris/ $\mathrm{HCl}, \mathrm{pH} 7-9 ; 20 \mathrm{mM}$ carbonate, $\mathrm{pH} 9-11$ ) for 30min and the residual enzyme activity was assayed. The stability of the celluloytic enzyme under various temperature (d) was determined by incubating the enzyme in $20 \mathrm{mM}$ Tris/ $\mathrm{HCl}$ buffer (pH 7.0) for $30 \mathrm{~min}$ at different temperatures $\left(30-90^{\circ} \mathrm{C}\right)$
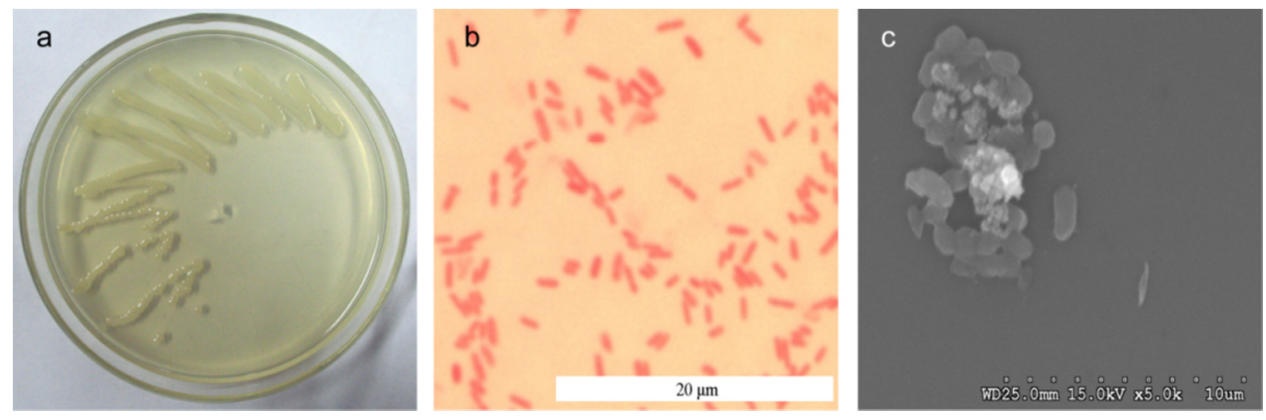

Fig. 3: The morphological observation of strain SWU-27. (a) colonies on nutrient LB agar medium,(b) the result of Gram method staining, $(\mathrm{c})$ observation under electron microscope $(\times 5000)$

16S rDNA sequence of strain SWU-27 has been deposited in the GenBank database under the accession No. EU128493.

\section{Discussion}

More and more fungi, such as Trichoderma and Aspergillus, have been isolated for highly producing cellulase enzyme complex and employed for enzymatic conversion of cellulose to fermentable sugars (Bansal et al., 2014; Lutzen et al., 1983; Raghuwanshi et al., 2014). However, largescale cultivation of fungi was usually costly since they grow slow and coproduce high viscous polymers (Kuhad et al., 2011). Recently, bacteria has become an ideal candidate to produce large scale cellulases for their rapid reproduction and low requirement of culture medium. For the application in industry, cellulases are usually required to endure high temperature and high $\mathrm{pH}$. Therefore, challenging as it is, seeking an available cellulose-decomposing organism bears significant meanings. Up to date, cellulolytic enzymeproducing bacteria have been isolated from soil (Hakamada et al., 1997), and marine sediments (Annamalai et al., 2012). But most previously reported bacteria did not functionally work under the wide range of temperature and $\mathrm{pH}$ (Sleat $e t$ al., 1984; Taya et al., 1988; Trivedi et al., 2011; Tai et al., 2004). This seriously limited their wide application in industrial fermentation. More studies were focused on seeking for thermostable alkaline cellulase-producing 


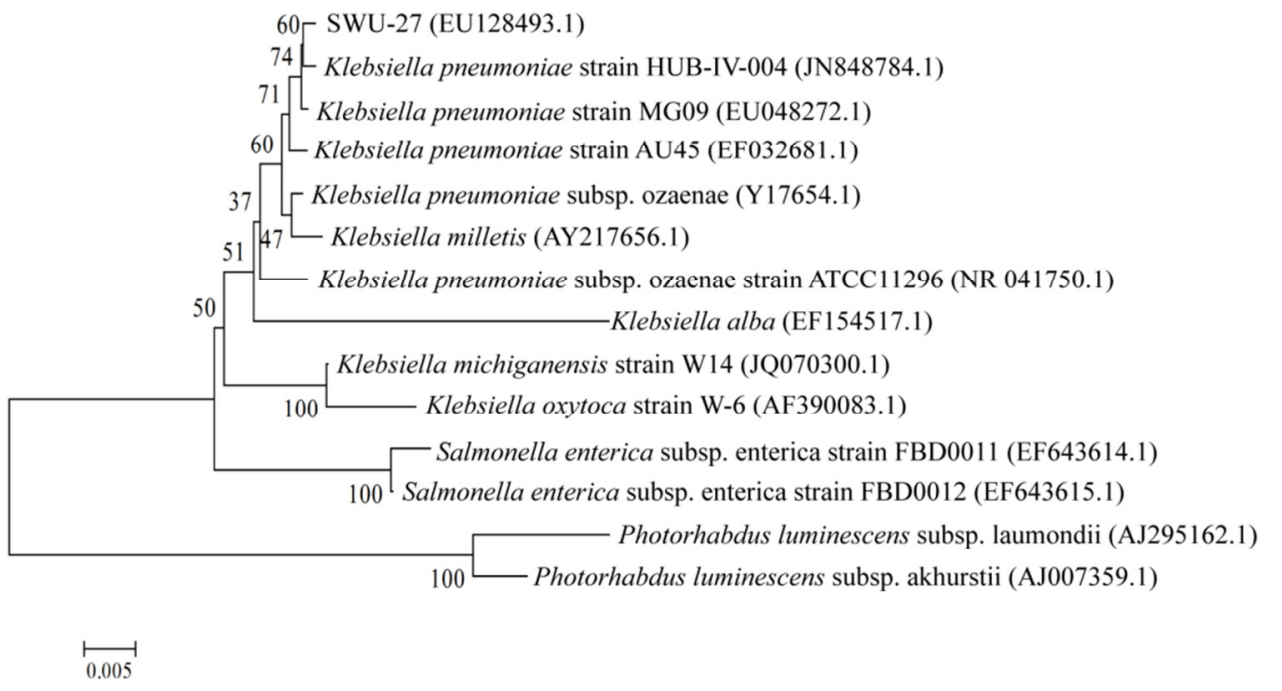

Fig. 4: Phylogenetic tree based on 16S rDNA gene sequences using the Neighborhood-joining method. Numbers at nodes indicate percentages of 1,500 bootstrap resamplings; Bar 0.005 sequence divergence; The codes after the names are the GenBank Accession numbers

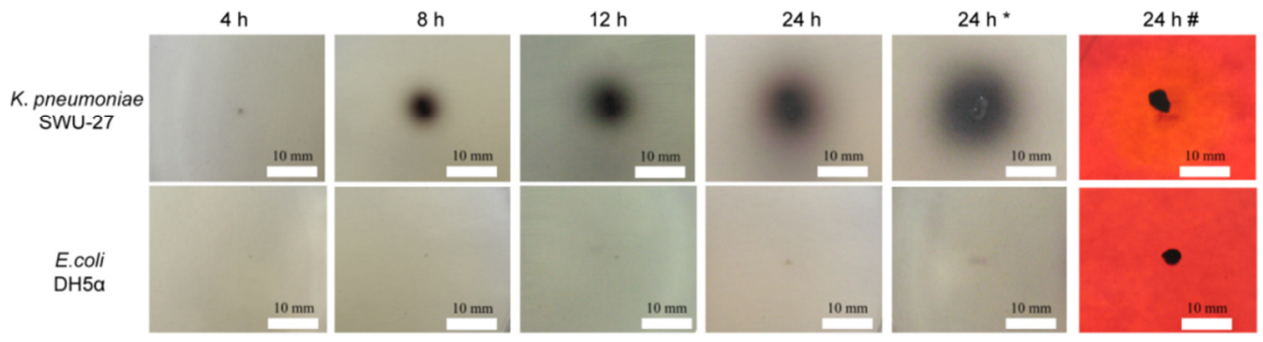

Fig. 5: Test on cellulolytic activities of strain SWU-27 under different time points after inoculation. The strain apparently showed black hydrolysis circle on Esculin plate and a transparent zone on CMCNa agar plate. E. coli strain DH5 $\alpha$ was employed as a negative control. Asterisk and pound sign indicated tests on Esculin plate and CMCNa agar plate, respectively

bacteria.

In this study, a bacterium was screened as a high yield cellulolytic-producing strain, K. pneumoniae SWU-27. The $16 \mathrm{~S}$ rDNA analysis proved that strain SWU-27 was a member of K. pneumoniae and the results of morphological, biochemical and physiological tests, obeying to the Bergey's Manual of Systematic Bacteriology, confirmed these results. In previous studies, $K$. oxytoca have the phenol-degrading activity and have been certified to produce ethanol and 2, 3butanediol from xylose and glucose (Ji et al., 2009). The mechanism and improvement of producing 1,3-propanediol and extended spectrum beta-lactamases by $K$. pneumoniae had become the main focuses of the previous studies (Menzel et al., 1997; Pena et al., 1998). But no research before ours was found to describe $K$. pneumoniae as a source of extracellular alkali-thermotolerant cellulolytic enzyme.

Strain SWU-27 was isolated directly from the samples just because of the superior capacity of degrading CMC substrates, Filter paper. Meanwhile, the cellulase system of the strain, SWU-27, showed notably higher $\beta$-glucosidase, which was both significant for splitting the cellulose into monosaccharide, accompanied with a rapid production. Immediately after stabinoculation for $4 \mathrm{~h}$, the black hydrolysis circle appeared as soon as the formation of the colony was initiated (Fig. 5). A clear black zone was larger and larger around strain SWU-27 as time passed. Meanwhile, a clear orange zone was also observed around the colony of SWU-27 after congo red stain, which suggested a CMCase activity. The rapid growth rate with timely production for cellulase of strain SWU-27 indicated the potential commercial value of this newly isolated bacterial strain.

\section{Conclusion}

The $K$. pneumoniae strain SWU-27 proved as a cellulase high-yielding organism. The characters of low nutritional requirement, rapid growth speed and highly stable enzyme system, which can endure high temperature and high $\mathrm{pH}$, suggested a potential application during the industrial progress towards biomass utilization. 


\section{Acknowledgement}

This study was supported by grants from the National Hightech R\&D Program (863 Program, No. 2013AA102507 and 2012AA101301), the National Natural Science Foundation of China (No. 31402142), the Fundamental and Advanced Research Projects of Chongqing Science and Technology Commission (No. cstc2014jcyjA80039), the Scientific and Technological Research Program of Chongqing Municipal Education Commission (Grant No. KJ110611, KJ10627 and KJ090813), the Natural Science Foundation Project of CQ CSTC (No. 2012jjA80006), the Key Project of Ministry of Education of China (No. 210180). We thank all of the people who assisted us in this study.

\section{References}

Annamalai, N., M.V. Rajeswari, S. Elayaraja, R. Thavasi, S. Vijayalakshmi and T. Balasubramanian, 2012. Purification and characterization of thermostable alkaline cellulase from marine bacterium Bacillus licheniformis AU01 by utilizing cellulosic wastes. Waste Biomass Valor, 3: 305-310

Bansal, N., C. Janveja, R. Tewari, R. Soni and S.K. Soni, 2014. Highly Thermostable and $\mathrm{pH}-\mathrm{Stable}$ Cellulases from Aspergillus niger NS-2: Properties and Application for Cellulose Hydrolysis. Appl. Biochem. Biotech., 172: 141-156

Benoit, L., C. Cailliez, E. Petitdemange and J. Gitton, 1992. Isolation of cellulolytic mesophilic clostridia from a municipal solid waste digestor. Microbial. Ecol., 23: 117-125

Bhikhabhai, R., G. Johansson and G. Pettersson, 1984. Isolation of cellulolytic enzymes from Trichoderma reesei QM 9414. J. Appl. Biochem., 6: 336

Garrity, G.M., D.J. Brenner, N.R. Krieg and J.T. Staley, 2005. Bergey's Manual of Systematic Bacteriology, $2^{\text {nd }}$ edition, Volume 2, part A. Springer-Verlag New York Inc., New York, USA

Gritzali, M. and R.D. Brown, 1979. The cellulase system of Trichoderma Adv. Chem. Ser., 12: 237-260

Hakamada, Y., K. Koike, T. Yoshimatsu, H. Mori, T. Kobayashi and S. Ito, 1997. Thermostable alkaline cellulase from an alkaliphilic isolate Bacillus sp. KSM-S237. Extremophiles, 1: 151-156

Huber, J.A., D.A. Butterfield and J.A. Baross, 2002. Temporal changes in archaeal diversity and chemistry in a mid-ocean ridge subseafloor habitat. Appl. Environ. Microbiol., 68: 1585-1594

Ji, X.J., H. Huang, J. Du, J.G. Zhu, L.J. Ren, N. Hu and S. Li, 2009. Enhanced 2, 3-butanediol production by Klebsiella oxytoca using a two-stage agitation speed control strategy. Bioresour. Technol., 100: 3410-3414

Kuhad, R.C., R. Gupta, Y.P. Khasa, A. Singh and Y.P. Zhang, 2011 Bioethanol production from pentose sugars: Current status and future prospects. Renew. Sust. Energ. Rev., 15: 4950-4962
Kwon, K.S., J. Lee, H.G. Kang and Y.C. Hah, 1994. Detection of betaglucosidase activity in polyacrylamide gels with esculin as substrate. Appl. Environ. Microbiol., 60: 4584

Lutzen, N.W., M.H. Nielsen, K.M. Oxenboell, M. Schulein and B. Stentebjerg-Olesen, 1983. Cellulases and their application in the conversion of lignocellulose to fermentable sugars. Phil. Trans. Royal Soc. London B., 300: 283-291

Mandels, M. and E.T. Reese, 1957. Induction of cellulase in Trichoderma viride as influenced by carbon sources and metals. J. Bacteriol., 73: 269

Menzel, K., A.P. Zeng and W.D. Deckwer, 1997. High concentration and productivity of 1, 3-propanediol from continuous fermentation of glycerol by Klebsiella pneumoniae. Enzyme Microb. Technol., 20: $82-86$

Miller, G.L., 1959. Use of dinitrosalicylic acid reagent for determination of reducing sugar. Anal. Chem., 31: 426-428

Pena, C., M. Pujol, C. Ardanuy, A. Ricart, R. Pallares, J. Linares, J. Ariza and F. Gudiol, 1998. Epidemiology and successful control of a large outbreak due to Klebsiella pneumoniae producing extendedspectrum beta-lactamases. Antimicrob. Agents Chemother, 42: 53

Raghuwanshi, S., D. Deswal, M. Karp and R.C. Kuhad, 2014. Bioprocessing of enhanced cellulase production from a mutant of Trichoderma asperellum RCK2011 and its application in hydrolysis of cellulose. Fuel, 124: 183-189

Rastogi, G., G.L. Muppidi, R.N. Gurram, A. Adhikari, K.M. Bischoff, S.R. Hughes, W.A. Apel, S.S. Bang, D.J. Dixon and R.K. Sani, 2009 Isolation and characterization of cellulose-degrading bacteria from the deep subsurface of the Homestake gold mine, Lead, South Dakota, USA. J. Ind. Microbiol. Biotechnol., 36: 585-598

Shuler, M.L., 1980. Utilization and Recycle of Agricultural Wastes and Residues. CRC Press Inc, Boca Raton, Florida, USA

Singh, P., A. Suman, P. Tiwari, N. Arya, A. Gaur and A.K. Shrivastava, 2008 Biological pretreatment of sugarcane trash for its conversion to fermentable sugars. World J. Microb. Biot., 24: 667-673

Sissons, C.H., K.R. Sharrock, R.M. Daniel and H.W. Morgan, 1987. Isolation of cellulolytic anaerobic extreme thermophiles from New Zealand thermal sites. Appl. Environ. Microbiol., 53: 832

Sleat, R., R.A. Mah and R. Robinson, 1984. Isolation and characterization of an anaerobic, cellulolytic bacterium, Clostridium cellulovorans sp. nov. Appl. Environ. Microbiol., 48: 88

Tai, S., H.P. Lin, J. Kuo and J. Liu, 2004. Isolation and characterization of a cellulolytic Geobacillus thermoleovorans T4 strain from sugar refinery wastewater. Extremophiles, 8: 345-349

Taya, M., H. Hinoki, T. Yagi and T. Kobayashi, 1988. Isolation and characterization of an extremely thermophilic, cellulolytic, anaerobic bacterium. Appl. Microbiol. Biotechnol., 29: 474-479

Trivedi, N., V. Gupta, M. Kumar, P. Kumari, C. Reddy and B. Jha, 2011. An alkali-halotolerant cellulase from Bacillus flexus isolated from green seaweed Ulva lactuca. Carbohyd. Polym., 83: 891-897

Zhou, J., Y.H. Wang, J. Chu, Y.P. Zhuang, S.L. Zhang and P. Yin, 2008 Identification and purification of the main components of cellulases from a mutant strain of Trichoderma viride T 100-14. Bioresour. Technol., 99: 6826-6833

(Received 07 July 2014; Accepted 27 August 2014) 